\title{
On a Verse Quoted in the Tibetan Translation of the Mahāyānasamgrahopanibandhana
}

\section{Noriaki Hakamaya}

\author{
I
}

There are quite a few differences between the Tibetan and the Chinese (Hsüan-tsang's) translations of the Mahāyannasamgrahopanibandhana. These differences are classified into three groups:

(1) The passages in both translations show differences in contents with each other.

(2) The passages in the chinese are not found in the Tibetan.

(3) The passages in the Tibetan are not found in the Chinese.

As a result of our former considerations of the differences belonging to groups (1) (2), we have judged that most of them can be attributed to Hsüan-tsang's addition, and that the Tibetan is more faithful to the original ${ }^{1}$.

In this paper, we will take up an example from the differences belonging to group (3) and examine it.

\section{II}

Asanga defines the nirvikalpajñana in his Mahayaanasamgraha, Chap. VIII,

1) See my articles: "Hsüan-tsang's translation of the Mahayanasamgrahopanibandhana (in Japanese)", JIBS, XVIII-1, (1969), pp. 140-141; "Some features of Asvabhāva's Mahāyanasmgrahopanibandhana, according to its Tibetan translation (in Japanese)", JIBS, XIX-1, (1970), pp. 439-444; "MAHĀYĀNASAMGGAHOPANIBANDHANA (I) - Its Tibetan and Chinese Texts_- Introduction", Journal of the Faculty of Buddhism XXXI, (Komazawa Univ., 1973), pp. 362-368. But the judgement is reserved for two examples which are treated in my third article. 
On a Verse Quoted in the Tibetan Translation of the MSU (N. Hakamaya)

$\S 2$ from the five points of $v_{i e w}^{2}$. Asvabhāva gives his following interpretation on the third difinition of them. We are going to show this paragraph, comparing the Tibetan with the Chinese.

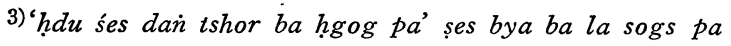
yan gal te hִdu śes dañ tshor ba rnam par și ba rnam par mi rog pa yin na ni des na rnam par mi rtog pahi ye ses ñid du mi hgyur te*/ sems med par sems las byun ba 4) 若想受滅是無分別智, 此 智體相難可成立. 無想等中, 離心無有諸心法故. 由意識 rnams mi hbyun bahi phyir roll hgog pahi sñoms par 滅, 說彼無心, 如前已說.

hjug pa la sogs pa la yid kyi rnam par śes pas sems dan bcas pa nid du hgal tel

sems las byun ba med par nil

/**sems ni nam kyañ ${ }^{* * *}$ mi ḩbyun tel

|** ñ ma dan ñi hod zer bșin/

/**de dag ñid dain lhan cig hbyuun ${ }^{5}$ )/

șes ji skad**** bśad pa lta buholl

\section{III}

The third difinition by Asanga exposes that the nirvikalpajñana differs from the state of asamjnin-samäpatti or nirodha-samapatti about which Abhidharmists had discussed from early times whether it is sacittaka (a state with thought) or acittaka (a state without thought)6).

2) É. Lamotte, La somme du grand véhicule d'Asanga, Tome I, p. 75; Tome II, pp. 233-234. The parallel passage very close to the five definitions of nirvikalpajñana is also recognized in the Dharmadharmatāvibhagga (Tib. trans., P. ed., No. 5523, Phi, $50 \mathrm{~b}^{5-6}$ or No. 5524, Phi, 54a $\mathrm{a}^{1-2}$ ) and the Abhidharmasamuccaya (Tib. trans., D. ed., No. 4049, Ri, $74 \mathrm{a}^{2-5}$ ).

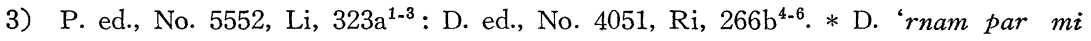
hgyur te'. ** P. om. '/ or '/l'. *** D. 'nams kyañ'. **** D. om. 'ji skad'.

4) Taisho ed., XXXI, p. 429c. Its French translation is given by É. Lamotte in his op. cit., Tome II, p. 234.

5) I cannot trace the quotation in a verse form to its sources, but can recognize a passage very close to it in the Lainkāvatārasütra (Nanjo ed., p. 227, 11. 13-15) which is as follows: "yaḥ punar Mahāmate tad-āśraya-pravṛtto vikalpaś cittacaitta-saṃśabdito yugapat-kālôdita āditya iva raśmi-sahito vicitra-lakṣaṇa-svabhāvo vikalpâdhārah sa Mahāmate svabhāvaḥ paratantra ity ucyate/". 
Asvabhāva admits these two samãpattis as acittaka from the standpoint of the Vijñaptimätrata $\bar{a}$ system. Therefore, he declares in his interpretation that there are not any caittas (functions of thought) without citta, and quotes a verse in order to prove the dependence of caittas upon citta.

However, the equivalent to the verse in the Tibetan cannot be found in the Chinese. Here the question is which one of these two translations is more faithful to the original.

If we suppose that the result of our former considerations can be adapted to this case and so that the Tibetan conserves the original form, it will be necessary to explain the reason why Hsüan-tsang (the Chinese) omitted the verse from its original.

The Chêng-wei-shih-lun (成唯識論) by Hsüan-tsang on which the tradition of the Fa-hsiang school (法相宗) has been founded asserts that this work is written for the purpose to refuse a certain advocater who adheres that there are not any caittas without citta ${ }^{7}$.

The verse in the Tibetan shows the meaning which cannot be accepted by the $C h^{'} \hat{e} n g$-wei-shih-lun. Therefore, it may be possible that Hsüan-tsang dared not translate it in order to conceal its meaning unfavourable to $\mathrm{him}^{8)}$.

6) Cf. the Abhidharmakośabhāṣya, "Bhadanta-Vasumitras tv āha Paripṛcchāyāṃ 'yasyâcittakā nirodha-samāpattis tasyâișa doṣo mama tu sacittakā samāpattir' iti/ Bhadanta-Ghoșaka āha tad idaṃ nôpapadyate/" (P. Pradhan ed. p. 72, 11. 21-22). Discussion of the same kind is treated in the Karmasiddhiprakarana (Tib. trans., S. Yamaguchi ed., p. 16: P. ed., No. 5563, Si, 162a) in which the same passage as the underlined above is shown, that is, "btsun pa dbyig gśes kyis yoins su dris pa las/ 'gañ gi ltar na hgog pahi sñoms par hjug pa sems med pa yin pa de la skyon de yod kyil kho bohi ltar na hgog pahi sñoms par hijug pa sems dai bcas pa ñid yin pas' ses smras pa".

7) “或執離心無別心所”. (Taisho ed., XXXI, p. la : Louls de la Vallée Poussin trans., p. 4). G. M. Nagao has already pointed out that this assertion by the $C h^{\text {' }}$ engwei-shih-lun is peculiar to the tradition of the Fa-hsiang school ("The Writer's Motive in “Hsüan-chuang's (玄牀) Vijñaptimātratāsiddhi”, The Tōhō Gakuhō, IX, (Kyoto, 1938), pp. 197-217).

Chi (基) regards the early Vijñaptivādins (二上古大乘) who are based on the Mahāyānasütrālaṇkāra as such an advocater (成唯識論掌中樞要, Taisho ed., XLIII, p. 617a). 


\section{IV}

There is also a possibility that the Tibetan and the Chinese had been based on the recensions different from each other, in case our conjecture mentioned above is not accepted. Considering such a possibility, we will try to understand each paragraph cited above in context of both translations. In the Tibetan, we can recognize another paragraph with almost the same quotation as the verse in question, which is as follows:

9). 'sems tsam'* șes bya ba la sogs pa la sems ni rnam par rig pa dan don gcig gol tsam gyi sgras ni don sel bar byed del de med pas hdsin pa yan sel tel brtags pahi phyir roll de sems las byun ba med par mi hbyun bahi phyir sems las byun ba rnams ni mi dgag stel.ji skad du sems las byun ba rnams med par sems nam yan mi hbyun $\dot{n ்}^{10)}$ șes bya ba la sogs pa gsuns pa lta buholl hgog pahi sñoms par hjug pa gan yin pa dehi sems** ji lta bu șe nal hdi ni phyogs can la ñes par hgyur roll kho bo cag la ni de na sems gan yod pa de mtshuns par ldan pa dan bcas par yod dol/ de ni mtshuns par ldan pa dan bcas su med do ${ }^{11) / /}$

We can understand from this paragraph that (1) citta conprises caittas, ${ }^{12}$ ) (2) the same quotation as the former half of the verse in question is of great use in proving the dependence of caittas upon citta and (3) the subject of citta and caitas refers in general to nirodhasamäpatti.

According to this understanding, it is suitable for the Tibetan to show the verse in question in Asvabhāva's interpretation on the third difinition of nirvikalpajñana (which refers to nirodhasamäpatti).

Returning to the Chinese paragraph cited above, let us take notice of its phrase '如前已說 (it is just like as explained before)' which is not found in the

8) However, there is an example that Hsüan-tsang (= the $C h^{\prime}$ êng-shih-lun) uses the quotation (which Commentaries trace to the Lañkāvatära, cf. note 5) very close to the verse as the opposite evidence (Taisho ed., p. 37a: Poussin, op. cit., p. 396). Nevertheless, I belive that his usage departs from its original meaning.

9) It is in the interpretation on the Mahãyanasamgraha, Chp. II, § 7, P. ed., No. 5552, Li, $270 \mathrm{~b}^{7}-271 \mathrm{a}^{3}$ : D. ed., No. 4051, Ri, 221a $\mathrm{a}^{4-7}$.

* P. 'can'. ** P. om. 'sems'.

10) If one syllable is supplemented in the quotation underlined, it is the same as the former half of the verse cited above which is found in the Tibetan only. 
Tibetan. It is important to consider the phrase in the Chinese context.

If we can suppose that Hsüan-tsang avoided to repeat quoting the verse in question by his insertion of the phrase, the phrase would indicate the quotation equivalent to that of the Tibetan which is almost the same as half of the verse in question. ${ }^{13)}$ However, it is impossible to think so in the Chinese context, because the phrase '如前已說' is expected to indicate the passage that deals with the subject of '無心 (acittaka)' by '意識滅 (the destruction of manovijñana)'.

But as there are several passages which deal with such a subject in Asvabhāva's interpretation, it is difficult to decide the place indicated by the phrase. ${ }^{14)}$ So far as I know, there are very few cases in which this sort of phrase '如前 已說 (yatha pürvam uktah.......)' is used in such a equivocation in the original Sanskrit, though the phrase is not unnatural within its Chinese context.

On the contrary, the original which is expected from the Tibetan with the verse in question seems to be more natural. So it seems to us that the Chinese paragraph with ‘如前已說’ is allowing some arrangement by Hsüan-tsang rather than to think it is based on another recension different from the Tibetan.

(昭和 48 年度文部省科學研究費[獎墍研究] よる研究成果の一部)

11） The Chinese equivalent to the above is as follows: “唯有心」者，心識是一.「唯」 蹈爲遣所取境義. 由彼無故, 能取亦無. 不遮心法, 由彼與心不相離故. 如說, 若無心 所有法, 心未曾轉. 若爾, 滅定何故唯心. 是彼宗過. 我大乘宗, 若處有心, 必定亦有 心相應法, 若處無有心相應法, 心亦定無. (Taisho ed., XXXI, p. 400b).

Both the translations agree with each other except that the Chinese omits the phrase equivalent to the Tibetan 'brtags pahi phyir ro'.

12) This interpretation agrees with that of the Vijnaptimätratā system such as Vasubandhu and Sthiramati. Cf. Michio Katano, "A Tradition of the Asvabhäva's. school —with the basis of a Tibetan Text——, Buddhist Seminar, XVIII, (Otani Univ., 1973), pp. 67-81, in which the author tries to examine the historical position of Asvabhāva according to the critical approach that I have already claimed in my articles (cf. note, 1).

13) See the passage underlined in note 11.

14) For example, É. Lamotte indicates the place (Taisho ed., XXXI, p. 384c) with interpretation on the MS, Chap. I, $\S 7$ in his French translation (op. cit., Tome II, p. 234c). It is also possible that the phrase indicates the place (Taisho ed., XXXI, p. 395c) with interpretation on the MS, Chap. I, § 52. 